\title{
Uji Efek Inhibitorik Komponen Bioaktif Bawang Putih (Allium sativum) terhadap Lanosterol 14a-demethylase pada Candida albicans melalui Studi In Silico
}

\section{Inhibitory Effect of Bioactive Compound in Garlic (Allium sativum) Against Lanosterol 14a-demethylase of Candida albicans through In Silico Study}

\author{
Aditya Tri Ananda ${ }^{1 *}$, Alsya Firdausi Nuzula ${ }^{2}$, Devi Ayu Safitri ${ }^{1}$ \\ ${ }^{1}$ Prodi Kedokteran Hewan, Fakultas Kedokteran Hewan, Universitas Airlangga \\ Jalan Mulyorejo Kampus C Surabaya 60115, Jawa Timur, Indonesia \\ ${ }^{2}$ Prodi Kimia, Fakultas Sains dan Teknologi, Universitas Airlangga \\ Jalan Mulyorejo Kampus C Surabaya 60115, Jawa Timur, Indonesia \\ *Email: adityataaa@gmail.com *Penulis Korespondensi
}

\begin{abstract}
Candida albicans is a unicellular fungi which causes candidiasis in human and livestock animals especially chicken. Candidiasis could reduce productivity significantly by early culling and causing a great deficit in the farm. Allium sativum or garlic is widely known as herbal which has an inhibitory effect in fungi's growth. This research's aim is to prove the effectivity of bioactive compound in Allium sativum to lanosterol 14a-demethylase which plays a role in ergosterol synthesis as a basic structure in fungi's cell membrane. The ligand sheet retrieved from PubChem database and for the receptor in Protein Data Bank database. Molecular docking conducted by using Autodock Vina and then ligand-receptor complex is visualized with PyMOL and Ligplot+. From compounds that we have been analyzed, Gallic Acid has the most negative binding energy than other compounds have and it has the same amino acid residue with control. In conclusion of that, Gallic Acid in Allium sativum has potential as anti-candidiasis drug.
\end{abstract}

Keywords : Gallic Acid, Candidiasis, Candida albicans, lanosterol 14a-demethylase

\begin{abstract}
Abstrak
Candida albicans merupakan jamur uniseluler yang menyebabkan penyakit candidiasis pada manusia maupun hewan ternak terutama unggas. Candidiasis dapat menyebabkan penurunan produktivitas ternak secara signifikan karena afkir terlalu dini dan menimbulkan kerugian yang sangat besar. Allium sativum atau bawang putih dikenal masyarakat luas sebagai herbal yang mempunyai efek menghambat pertumbuhan jamur. Penelitian ini bertujuan untuk membuktikan khasiat komponen bioaktif yang terdapat pada Allium sativum terhadap reseptor lanosterol $14 \alpha$-demethylase yang berperan penting dalam sintesis ergosterol sebagai bahan dasar pembentukan membran sel jamur. Berkas ligan didapatkan melalui database Pubchem dan reseptor dari Protein Data Bank. Tambatan molekuler dilakukan dengan menggunakan Autodock Vina lalu kompleks ligan-reseptor divisualisasikan dengan menggunakan PyMOL dan Ligplot+. Dari komponen yang dianalisis, Gallic Acid mempunyai energi ikatan paling negatif dari komponen yang lain serta residu asam amino yang mirip dengan kontrol. Berdasarkan hal tersebut,Gallic Acid dalam Allium sativum dapat dijadikan sebagai calon obat anti candidiasis.
\end{abstract}

Kata Kunci : Gallic Acid, Candidiasis, Candida albicans, lanosterol 14a-demethylase

Diterima: 12 Januari 2020, disetujui: 10 Mei 2020

\section{Pendahuluan}

Candida albicans (C.alb) merupakan jamur uniseluler yang menyebabkan penyakit candidiasis yang menyerang hewan ternak terutama unggas. Jamur tersebut mempunyai predileksi penyakit pada saluran pencernaan, saluran pernapasan, saluran reproduksi, kulit dan mata dan seringkali ditandai dengan perubahan patologis post mortem seperti 
pseudomembrane dan nodul pada mukosa serta terdapat ulcer dan haemorrhagi ( Calderone \& Fonzi, 2001). Candidiasis merupakan masalah utama pada peternak unggas karena dapat menurunkan produktivitas daging dan telur karena pengafkiran yang terlalu dini dan dapat menimbulkan kerugian yang sangat besar bagi peternak (Eni, 2010).

Infeksi oppurtunistik dari C.alb sangat dipengaruhi oleh faktor predisposisi seperti penggunaan antibiotik dan kortikosteroid yang terlalu lama dan faktor imunitas individu yang menurun. Infeksi dari C.alb dapat diatasi dengan pemberian obat anti jamur yang tersedia di pasaran seperti nystatin dan ketoconazole ( Hann et al., 1982). Obat-obatan tersebut berikatan dengan lanosterol $14 \alpha$ demethylase yang berfungsi untuk mengubah lanosterol menjadi 4,4-dimethylcholesta8(9),14,24-trien-3 $\beta$-ol atau bisa dikenal dengan ergosterol (Aoyama et al., 1984; Trösken et al., 2006). Hambatan pada enzim tersebut dapat mengganggu sintesis senyawa golongan sterol pada C.alb terutama pada sintesis ergosterol yang penting dalam pembentukan membran sel C.alb.

Penggunaan obat-obatan yang menghambat sintesis senyawa sterol tersebut secara terus menerus dapat menimbulkan masalah yang serius seperti resistensi obat pada C.alb yang menyebabkan medikasi di masa mendatang lebih sulit. Oleh karena itu, perlu dicarikan obat herbal alternatif yang mempunyai efek serupa dengan obat-obatan antijamur seperti nystatin dan ketoconazole.

Bawang putih (Allium sativum) dipercaya memiliki efek anti jamur dan kerap dipakai sebagai obat herbal untuk mengatasi infeksi jamur (Djaenuddin , 2010; Kutawa et al., 2018; Sari, 2014). Oleh karena itu, penelitian ini bertujuan untuk menganalisis komponen bioaktif yang terdapat pada Allium sativum terhadap lanosterol $14 \alpha$-demethylase dengan menggunakan tambatan molekuler (molecular docking) sehingga didapatkan informasi molekuler mengenai energi ikatan dan interaksi molekuler diantara senyawa tersebut.

\section{Metode Penelitian}

\section{Preparasi Reseptor dan Ligan}

Reseptor yang digunakan pada penelitian ini merupakan lanosterol 14 $\alpha$ demethylase yang didapat dari Protein Data Bank / PDB (PDB, 2019)dengan id 4LXJ. Kemudian dipreparasi dengan menghilangkan ligan dan molekul air yang berikatan dengan protein tersebut lalu disimpan dalam format pdbqt.

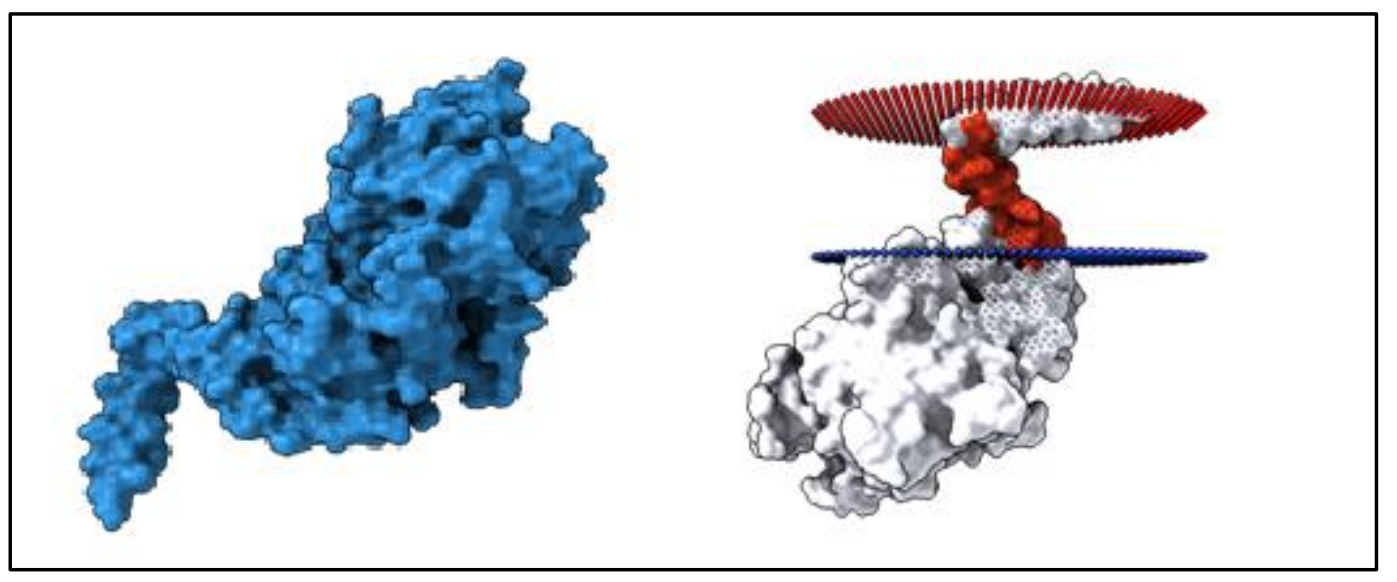

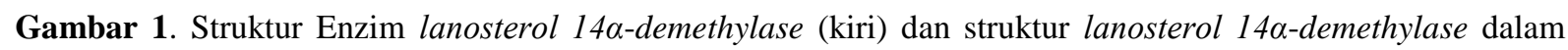
mode transmembran (kanan) (PDB, 2019)

Senyawa bioaktif dari Allium sativum menurut herbaldb (Djaenuddin, 2010)adalah Gallic Acid, Alliin, Allicin, dan 2-Vinyl-4H.
Kemudian konformasi senyawa tersebut diunduh pada situs Pubchem (Kim et al., 2016) lalu dikonversikan dalam file berbentuk pdbqt. 


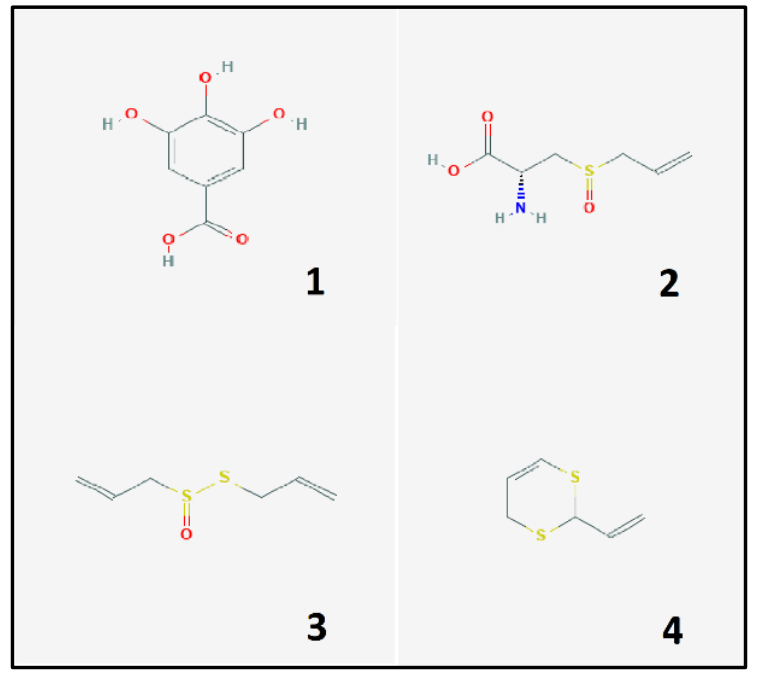

Gambar 2. Struktur Kimia Komponen Bioaktif dari Allium sativum; Gallic Acid (1), Allin (2), Allicin (3), 2Vinyl-4H (4) (Djaenuddin, 2010)

\section{Tambatan Molekuler (Molecular Docking)}

Pada penelitian ini, tambatan molekuler yang digunakan merupakan specific docking dimana grid untuk melakukan tambatan diletakkan di tengah reseptor guna mencari tempat ligan untuk bertautan.

Tambatan molekuler dilakukan dengan menggunakan autodock Vina dan Autodock 4.0 antara reseptor dan ligan yang telah dipreparasi (Seeliger \& Groot, 2010). Kompleks ligan-reseptor lalu diukur Energi ikatannya $\left(\Delta G_{i k a t a n}\right)$. Kompleks ligan-reseptor lalu divisualisasikan menggunakan pyMOL dan ilustrasi ikatan 2D menggunakan Ligplot+ untuk dianalisis jenis interaksi antara reseptor dan ligan ( Laskowski \& Swindells, 2011)

\section{Hasil dan Pembahasan}

\section{Analisis Energi Ikatan Kompleks Ligan- Reseptor}

Komponen bioaktif dari Allium sativum yang telah dipreparasi terlebih dahulu yaitu Alliin, Allicin, dan 2-Vinyl-4H ditambatkan dengan lanosterol 14 $\alpha$-demethylase dengan menggunakan Autodock Vina dan didapatkan Energi ikatan / Binding Affinity pada Tabel 1.

Tabel 1. Energi Ikatan antara kompleks ligan-reseptor. (Gallic Acid memiliki energi ikatan paling negatif diantara komponen bawang putih yang lain).

\begin{tabular}{ccc}
\hline \hline No & Ligand & Energi Ikatan (Kcal/mol) \\
\hline \hline 1 & Gallic Acid & -5.8 \\
2 & Alliin & -5.2 \\
3 & Allicin & -4.1 \\
4 & $2-V i n y l-4 H$ & -4.4 \\
5 & Ketoconazole (kontrol) & -8.2 \\
\hline \hline
\end{tabular}

Metode tambatan (docking) bertujuan untuk menentukan energi ikatan yang timbul ketika komponen dari Allium sativum bertautan dengan reseptor pada tempat/kawah tertentu pada permukaan reseptor. Untuk menentukan tempat komponen berikatan dengan reseptor digunakan metode grid dengan titik tengah / center sebesar $(\AA)$ X: $60.3 \mathrm{Y}: 50.5 \mathrm{Z}: 21.7$ dan ukuran dimensi sebesar $(\AA)$ X: 76 Y: $102 \mathrm{Z}$ :
108. Apabila komponen yang diuji memiliki tempat pertautan yang serupa dengan kontrol, maka dapat diasumsikan bahwa komponen tersebut memiliki efek yang sama dengan kontrol.

Energi ikatan dipengaruhi oleh Energi bebas Gibbs $(\Delta \mathrm{G})$, reaksi yang berlangsung secara spontan akan memiliki energi bebas gibbs yang benilai negatif pada suhu dan 
temperatur yang konstan. Energi ikatan dipengaruhi oleh beberapa komponen yang dinyatakan dengan persamaan berikut:

$$
\begin{aligned}
\Delta G_{\text {ikatan }}= & \Delta G_{\text {Gauss }}+\Delta G_{\text {Repulsi }}+ \\
& \Delta G_{\text {HBond }}+\Delta G_{\text {Hydrop hobic }}+ \\
& \Delta G_{\text {Torsion }}
\end{aligned}
$$

Semakin banyak komponen energi yang berkontribusi maka nilai $\Delta G_{\text {ikatan }}$ akan semakin kecil (menjadi negatif), imbasnya ikatan tersebut akan semakin kuat dan menimbulkan efek inhibitorik yang kuat (Kharisma et al., 2018; Trott \& Olson , 2010)

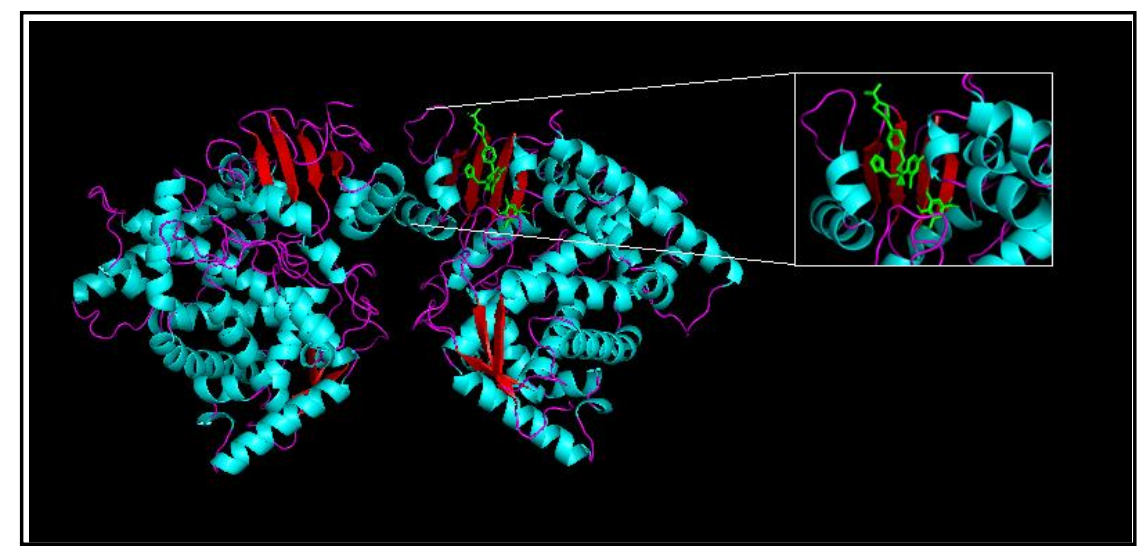

Gambar 3. Visualisasi letak pertautan antara Gallic Acid dan Ketoconazole pada lanosterol 14a-demethylase

Data pada Tabel 1 menunjukkan bahwa Gallic Acid memiliki energi ikatan sebesar $5.8 \mathrm{Kcal} / \mathrm{mol}$. Lebih rendah dibandingkan komponen lain yaitu Allin sebesar -5.2 $\mathrm{Kcal} / \mathrm{mol}$, Allicin sebesar - $4.1 \mathrm{Kcal} / \mathrm{mol}$ dan 2Vinyl-4H sebesar $-4.4 \mathrm{Kcal} / \mathrm{mol}$ sehingga Gallic Acid lebih memiliki efek inhibitorik pada reseptor lanosterol 14 $\alpha$-demethylase dibandingkan senyawa bioaktif yang lain. Gallic Acid juga memiliki tempat pertautan yang hampir serupa dengan Ketoconazole sehingga dapat diprediksi bahwa kedua komponen tersebut mempunyai efek yang sama seperti ketoconazole yakni menghambat enzim Lanosterol 14 $\alpha$-demethylase yang penting pada sintesis Ergosterol. Butuh uji lanjut secara in vitro dan in vivo untuk mengkonfirmasi efek inhibitorik gallic acid terhadap pertumbuhan Candida albicans.

\section{Analisis Ikatan Kompleks Ligan-Reseptor}

Hasil dari pertautan komponen tersebut lalu divisualisasikan secara 2D menggunakan Ligplot+ yang ditunjukkan pada Gambar 4.

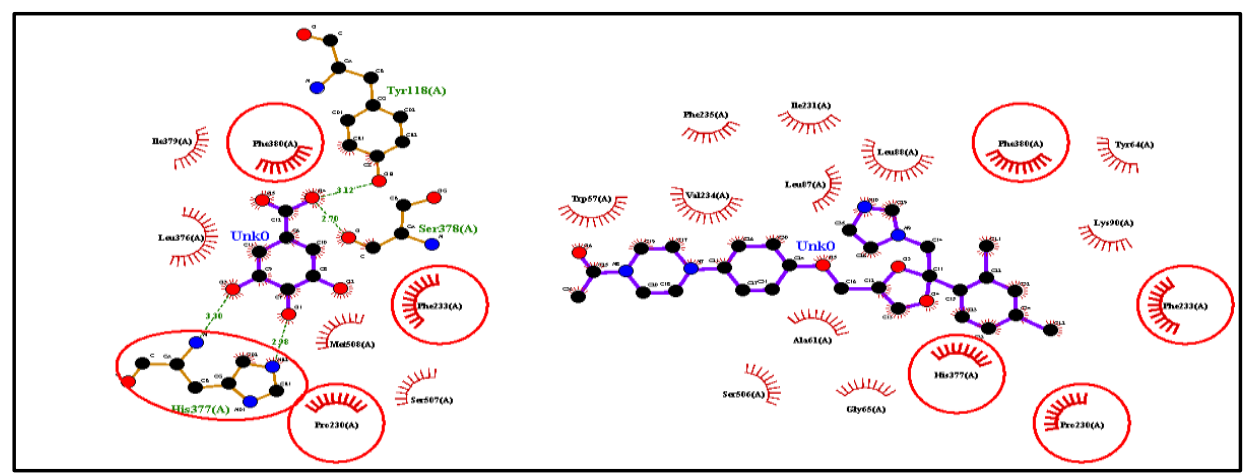

Gambar 4. Visualisasi Ikatan Gallic Acid pada tempat pertambatan (kiri) dan Ketoconazole (kanan). Lingkaran merah menunjukkan persamaan Asam amino antar dua komponen. Garis merah menunjukkan reaksi hidrofobik dan Garis hijau menunjukkan ikatan hidrogen. 
Garis merah pada visualisasi tersebut menunjukkan interaksi hidrofobik antara ligan dengan asam amino sedangkan garis hijau menunjukkan ikatan hidrogen antara ligan dengan asam amino. Secara umum, semakin banyak komponen dari ligan yang berinteraksi dengan reseptor akan dihasilkan energi ikatan
$\left(\Delta G_{\text {ikatan }}\right)$ yang rendah, imbasnya ikatan ligan akan kuat dengan reseptor dan diharapkan mampu menimbulkan efek inhibitorik terhadap reseptor (Kharisma et al., 2018; Laskowski \& Swindells , 2011).

Tabel 2. Interaksi Komponen bioaktif Allium Sativum dengan Lanosterol 14 $\alpha$-demethylase. Bagian dalam tabel yang dicetak tebal merupakan komponen interaksi yang sama dengan kontrol.

\begin{tabular}{|c|c|c|}
\hline No & Ligand & Interaksi \\
\hline$\overline{11}$ & Gallic Acid & $\begin{array}{l}\text { Hidrofobik : Phe380, Ile379, Leu376, Pro230, Met508, Ser507, } \\
\text { Phe233 } \\
\text { Ikatan Hidrogen : Ser378 (2.70), Tyr118 (3.12), His377 (3.30 dan } \\
\text { 2.98) }\end{array}$ \\
\hline 2 & Alliin & $\begin{array}{l}\text { Hidrofobik : Leu376, Tyr132, Leu121, Tyr118, Phe233 } \\
\text { Ikatan Hidrogen : His377 (3.01), Met508 (2.90), Ser378 (2.83 dan } \\
\text { 2.80) }\end{array}$ \\
\hline 3 & Allicin & $\begin{array}{l}\text { Hidrofobik : Ser222, Phe213, Ala218, Tyr221, Ile197, Asp225, } \\
\text { Pro193 } \\
\text { Ikatan Hidrogen : - }\end{array}$ \\
\hline $\mathrm{Y}$ & 2-Vinyl-4H & $\begin{array}{l}\text { Hidrofobik : Ile197, Glu194, Pro193, Asp225, Tyr221, Gln309 } \\
\text { Ikatan Hidrogen : - }\end{array}$ \\
\hline 5 & Ketoconazole (kontrol) & $\begin{array}{l}\text { Hidrofobik : Phe380, Tyr64, Lys90, Phe233, Pro230, His377, } \\
\text { Gly65, Ala61, Ser506, Leu88, Ile231, Phe235, Val234, Trp57, } \\
\text { Leu87 } \\
\text { Ikatan Hidrogen : - }\end{array}$ \\
\hline
\end{tabular}

Gallic Acid memiliki beberapa interaksi hidrofobik yang sama dengan ketoconazole (kontrol) yaitu pada asam amino Phe380, Phe233, dan Pro230. Sedangkan asam amino His377 memiliki interaksi ikatan hidrogen dengan Gallic Acid pada atom O. Hal tersebut menunjukkan bahwa komponen ini memiliki tempat pertautan yang hampir serupa dan mampu berikatan sangat kuat sehingga mampu memiliki efek seperti kontrol.

\section{Simpulan}

Kandungan Gallic Acid dalam Allium sativum berikatan kuat terhadap reseptor

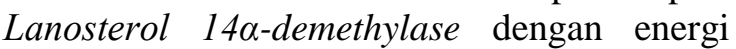
ikatan $-5.8 \mathrm{Kcal} / \mathrm{mol}$ dan residu asam amino yang sama seperti kontrol (Phe 380, Pro 230, Phe233, His377). Oleh karena itu, Gallic Acid berpotensi untuk dijadikan kandidat obat anticandida dengan menghambat lanosterol $14 \alpha-$ demethylase. Namun demikian perlu dilakukan studi lanjutan mengenai efek inhibitorik gallic acid terhadap pertumbuhan Candida albicans melalui studi in vitro dan in vivo.

\section{Daftar Pustaka}

Aoyama, Y., Yoshida, Y., \& Sato, R. (1984). Yeast cytochrome P-450 catalyzing lanosterol 14 alpha-demethylation. II. Lanosterol metabolism by purified P-450 (14) DM and by intact microsomes. Journal of Biological Chemistry, 259(3), 1661-1666.

Basis Data Tanaman Obat Indonesia. http://herbaldb.farmasi.ui.ac.id/v3/, diakses 12 Juni 2019

Calderone, R. A., \& Fonzi, W. A. (2001). Virulence factors of Candida albicans. Trends in microbiology, 9(7), 327-335.

Djaenuddin G. Pengujian penggunaan ekstrak etanol bawang putih (Allium sativum L.) terhadap kelinci yang diinfeksi dermatofit Trichophyton mentafrophytes. Seminar Teknologi Peternakan dan Veteriner; 2010, Balai Besar Penelitian Veteriner. p. 803-8

Eni K. Mekanisme infeksi Candida albicans pada permukaan sel. Lokakarya Nasional Penyakit Zoonis; 2010, Balai Besar Penelitian Veterenier. p. 304-13

Hann, I. M., Corringham, R., Keaney, M., Noone, P., Fox, J., Szawatkowski, M., \& Boesen, E. (1982). Ketoconazole versus nystatin plus amphotericin B for fungal prophylaxis in 
severely immunocompromised patients. The Lancet, 319(8276), 826-829.

Kharisma, V. D., Septiadi, L., \& Syafrudin, S. (2018). Prediction of Novel Bioactive Compound from Zingiber officinale as Non-nucleoside Reverse Transcriptase Inhibitors (NNRTIs) of HIV-1 through Computational Study. Bioinformatics and Biomedical Research Journal, 1(2), 49-55.

Kim S, Thiessen PA, Bolton EE, Chen J, Fu G, Gindulyte A, Han L, He J, He S, Shoemaker BA, Wang J, Yu B, Zhang J, Bryant SH. 2016. PubChem Substance and Com-pound databases. Nucleic Acids Res. 44 (D1): D1202-13. doi: 10.1093/nar/gkv951.

Kutawa, A. B., Danladi, M. D., \& Haruna, A. (2018). Antifungal Activity of Garlic (Allium sativum) Extract on Some Selected Fungi. Journal of Medicinal Herb and Etnomedicine Vol. 4, 1214.

Laskowski RA \& Swindells MB. 2011. LigPlot+: multiple ligand-protein interaction diagrams for drug discovery. J. Chem. Inf. Model 51: 27782786.doi: $10.1021 / \mathrm{ci} 200227 \mathrm{u}$.
Sari, M. E. S. Y. I. A. (2014). Pengaruh Perendaman Bahan Basis Gigi tiruan Valplast dalam Larutan Ekstrak Bawang Putih terhadap Pertumbuhan Candida albicans. Skripsi. FKG Universitas Hasanuddin, 20-17.

Seeliger D, \& de Groot BL. 2010. Ligand docking and bind-ing site analysis with PyMOL and Autodock/Vina. Journal of computer-aided molecular design 24(5): 417-422. doi: 10.1007/s10822-010-9352-6.

The Protein Databank. http://www.rcsb.org/pdb/home/home.do. diakses 12 Juni 2019

Trösken, E. R., Adamska, M., Arand, M., Zarn, J. A., Patten, C., Völkel, W., \& Lutz, W. K. (2006). Comparison of lanosterol-14 $\alpha$-demethylase (CYP51) of human and Candida albicans for inhibition by different antifungal azoles. Toxicology, 228(1), 24-32.

Trott, O., \& Olson, A. J. (2010). AutoDock Vina: improving the speed and accuracy of docking with a new scoring function, efficient optimization, and multithreading. Journal of computational chemistry, 31(2), 455-461. 